\title{
MOTIVASI PETANI DALAM MEMPERTAHANKAN SISTEM TRADISIONAL PADA USAHATANI PADI SAWAH DI DESA PARBAJU JULU KABUPATEN TAPANULI UTARA PROPINSI SUMATERA UTARA
}

\section{(THE MOTIVATION OF FARMERS TO PRESERVE THE TRADITIONAL SYSTEM OF PADDY SAWAH FARMING IN PARBAJU JULU VILLAGE NORTH TAPANULI COUNTY NORTH SUMATRA PROVINCE)}

\author{
Reflis, M. Nurung, Juliana Dewi Pratiwi \\ Jurusan Sosial Ekonomi Pertanian \\ Fakultas Pertanian \\ Universitas Bengkulu
}

\begin{abstract}
This research aims to identify factors correlated significantly to the motivation of farmers in perseving traditional rainfed farming systems, such as using local seeds and planting once a year. The population of this study is farmer who still perform the traditional paddy farming system in the Village of North Tapanuli Parbaju Julu County North Sumatra Province. As much as 48 respondents randomly selected from 160 farmers. A descriptive analyse and Spearman rank correlation are applied in this study. The study showed that formal education, farmers' perception of the traditional system of rice farming are correlated significantly to farmer motivation in preserving tradional farming system while non-formal education, the traditional system of farming experience, farm size, number of family members are not. Factors that correlated significantly to farmer motivation in maintaining local seed is non-formal education, farming experience, while the traditional system of formal education, farmers' perception of traditional rice farming system, farm size, number of family members are not correlated significantly. Furthermore, the number of family members is merely factor that correlated significantly to the farmers motivation in maintaining once a year plantings while others factors are not correlated.
\end{abstract}

Key words: farmer motivation, preserving, traditional farming

\section{PENDAHULUAN}

Peran sub sektor tanaman pangan dalam perekonomian masih sangat penting dan strategis, peranan penting dan strategis ini terutama dalam hal meningkatkan produksi untuk mencukupi kebutuhan pangan, seperti padi. Program peningkatan ketahanan pangan diarahkan untuk dapat memenuhi kebutuhan pangan masyarakat di dalam negeri dari produksi pangan nasional. Berbagai upaya telah ditempuh pemerintah melalui kegiatan pengamanan 
lahan, peningkatan mutu intensifikasi serta optimalisasi dan perluasan areal pertanian. Salah satu bahan pangan nasional yang diupayakan ketersediaannya tercukupi sepanjang tahun adalah beras yang menjadi makanan pokok bagi sebagian besar penduduk Indonesia.

Padi merupakan salah satu komoditas penting di dunia, sebab sekitar 90\% dihasilkan dan dikonsumsi sebagai makanan pokok bagi penduduk di negaranegara Asia dengan nilai perdagangan beras global mencapai US\$ 6,88 billion. Sedangkan di Indonesia beras merupakan bahan makanan pokok bagi sekitar 95\% penduduk dengan konsumsi beras 108-137 kg per kapita. Oleh karena itu peningkatan produksi padi di Indonesia harus tetap dilakukan lebih tinggi dari laju pertumbuhan penduduk yang mencapai rata-rata 1,3\% per tahun.

Padi adalah salah satu tanaman budidaya terpenting dalam peradaban, meskipun terutama mengacu pada jenis tanaman budidaya padi juga digunakan untuk mengacu pada beberapa jenis dari marga (genus) yang sama biasanya disebut sebagai padi liar. Padi merupakan tanaman yang banyak ditanam dan diusahakan oleh sebagian besar petani di kabupaten tapanuli utara. Kabupaten ini mempenyai luas lahan sawah yang potensial dalam menunjang produktivitas lahan sawah tersebut.

Sistem pertanian tradisional adalah pengetahuan yang khas milik suatu masyarakat atau budaya tertentu yang telah berkembang lama sebagai hasil dari proses hubungan timbal balik antara masyarakat dengan lingkungan. Jadi, konsep penerapan sistem padi tradisional berakar dari sistem pengetahuan dan pengelolaan lokal atau tradisional. Karena hubungan yang dekat dengan lingkungan dan sumber daya alam, masyarakat lokal, tradisional atau asli melalui uji coba telah dianggap mempertahankan sumber daya alam, serta meninggalkan kegiatan-kegiatan yang dianggap merusak lingkungan.

Sistem pertanian tradisional yang akrab dan selaras dengan alam, yang disesuaikan dengan situasi ekologi lokal seperti tipologi lahan dan keadaan musim yang erat kaitannya dengan keadaan tofografi, kedalaman genangan, dan ketersediaan air. Sistem pertaniaan tradisional yang dilakukan oleh penduduk Di Desa Parbaju Julu Kabupaten Tapanuli Utara Propinsi Sumatera Utara masih dikelolah secara tradisional mulai dari penggunaan bibit lokal, pengairan dengan tadah hujan dan panen satu kali dalam setahun.

Lahan sawah tadah hujan merupakan sumber daya fisik yang potensial untuk pengembangan pertanian, seperti padi, palawija dan tanaman holtikultura. Pada umumnya lahan sawah tadah hujan ini hanya ditanami padi sekali dalam setahun yaitu pada musim hujan, sedangkan pada musim kemarau sebagian diantaranya mengalami bera sampai pada musim tanam berikutnya. Bahkan pada beberapa daerah atau lokasi, lahan tidur akibat keterbatasan air dan pengolahan yang tidak benar. Padi yang ditanam adalah jenis lokal dengan ciri-ciri tanaman yang tinggi dan bisa berumur sampai kira-kira tujuh bulan siap dipanen. Mereka memilih bertahan mengembangkan padi lokal karena mampu bertahan disimpan 13-15 tahun.

Di Propinsi Sumatera Utara terutama di Kabupaten Tapanuli Utara merupakan salah satu sentra pertanian yang kesuburan tanahnya cocok untuk 
ditanami padi. Walaupun kesuburan tanahnya sudah cocok untuk tanaman padi, petani hanya melakukan penanaman sekali musim tanam dalam setahun. Kegiatan usahatani di daerah ini adalah padi dengan sistem mina padi, dimana usaha budidaya padi diselingi dengan kegiatan budidaya ikan mas atau tanaman cabe. Berdasarkan uraian diatas penulis merasa tertarik untuk melakukan suatu kajian terhadap fenomena keadaan ini. Penulis memilih judul "Analisis Motivasi Petani Dalam Mempertahankan Sistem Tradisional Pada Usaha Tani Padi Sawah Di Desa Parbaju Julu Kabupaten Tapanuli Utara Propinsi Sumatera Utara". Secara rinci permasalahan dalam penelitian ini adalah sebagai berikut :

1. Bagaimana motivasi petani dalam mempertahankan sistem tadah hujan, bibit lokal, dan penanaman sekali dalam setahun dengan sistem tradisional pada usaha tani padi sawah di Desa Parbaju Julu Kabupaten Tapanuli Utara Propinsi Sumatera Utara.

2. Faktor-faktor apa saja yang berhubungan nyata dan tidak nyata terhadap motivasi petani dalam mempertahankan sistem tradisional pada usaha tani padi sawah di Desa Parbaju Julu Kabupaten Tapanuli Utara Propinsi Sumatera Utara.

\section{METODE PENELITIAN}

\section{Pengumpulan Data}

Penelitian ini dilakukan secara sengaja (Purposive) Di Desa Parbaju Julu Kabupaten Tapanuli Utara Propinsi Sumatera Utara, dengan pertimbangan bahwa di Desa Parbaju Julu penduduknya mayoritas adalah petani padi. Responden dipilih secara acak (simple random sampling.) Data yang digunakan dalam penelitian ini adalah data primer dan data sekunder. Pengumpulan data yang dilakukan dalam penelitian ini adalah: wawancara mendalam (indepth interview) yaitu berupa dialog baik secara inividu maupun kelompok dengan informan dan responden, serta melakukabn pengamatan secara terlibat langsung (participant Observation) untuk mendapatkan informasi permasalahan yang lebih menyeluruh dan mendalam.

\section{Metode Analisis Data}

Analisis data yang digunakan untuk mengkaji motivasi petani dalam mempertahakan sistem tradisional pada usahatani padi sawah di Desa Parbaju Julu Kabupaten Tapanuli Utara Propinsi Sumatera Utara dilakukan dengan analisis deskriptif kualitatif. Menurut Nazir (1988), metode deskriptif kualitatif adalah suatu metode dalam penelitian suatu objek, suatu kelompok manusia, kondisi suatu sistem pemikiran ataupun suatu kelas peristiwa pada masa sekarang dengan tujuan untuk membuat deskriptif, gambaran atau lukisan secara sistematis, faktual dan akurat mengenai fakta-fakta, sifat-sifat serta hubungan antar fenomena yang diselidiki. Untuk mengetahui apakah ada 
hubungan antara variabel $\mathrm{X}$ dan variabel $\mathrm{Y}$ yang diamati digunakan alat analisis statistik non parametrik, yaitu uji korelasi Rank Spearman (Rs)

\section{HASIL DAN PEMBAHASAN}

\section{Tingkat Motivasi Petani dalam Mempertahankan Sistem Tradisional Padi Sawah}

Berdasarkan hasil penelitian tingkat motivasi petani mempertahankan sistem tradisional yang termasuk dalam kategori tinggi sebesar $50 \%$, kategori sedang sebesar 43,75\% dan kategori rendah sebesar 6,25\%. Dari data tersebut tingkat motivasi mempertahankan sistem tradisional termasuk dalam kategori tinggi, hal ini disebabkan tidak memerlukan biaya yang tinggi, perawatan rendah, penghasilan yang diperoleh dalam berusahatani sekali dalam setahun telah dapat memenuhi kebutuhan hidup keluarga sampai musim tanam berikutnya, dengan menggunkan bibit lokal maka resiko kegagalan panen relative kurang karena than terhadap hama dan penyakit.

\section{Motivasi Petani Mempertahankan Sistem Tadah Hujan}

Berdasarkan hasil penelitian tingkat motivasi petani mempertahankan sistem tadah hujan yang termasuk dalam kategori tinggi sebesar 33,333 \%, kategori sedang sebesar 35,4166 \% dan kategori rendah sebesar 31,25\%. Dari wawancara yang dilakukan langsung kepada petani (Manahan Hutabarat) sebagai informan "dang na olo hami mempertahankan aek udan on ale ala nasoa adong do pe na irigasi na di baen di desa on, las selama martani aek tarcukkupi do dohot aek udan" (kami tidak ingin mempertahankan tadah hujan tetapi karena belum ada irigasi di desa ini, dan selama berusahatani air masih tercukupi dengan sistem tadah hujan.

Dari data di atas dapat dilihat bahwa tingkat motivasi petani mempertahankan sistem tadah hujan termasuk dalam kategori sedang, hal ini disebabkan karena tidak teraturnya keadaan iklim pada sekarang ini. Masyarakat masih cenderung ingin mempertahankan sistem tadah hujan dan sebagian juga ingin mengusulkan kepada pemerintah agar memberi atau mendirikan sarana irigasi kepada masyarakat sehingga manfaat dan keuntungan yang mereka dapatkan optimal. Sedangkan petani yang memiliki motivasi tinggi disebabkan karena curah hujan yang cukup sehingga mampu untuk memenuhi dalam usahatani padi tanpa memerlukan irigasi, selain itu penghematan biaya juga dijadikan alasan bagi petani untuk tetap bertahan menggunakan sistem tadah hujan. Untuk petani yang memiliki motivasi rendah disebabkan karena petani sudah memiliki keinginan untuk menggunakan irigasi dengan alasan kebutuhan air akan selalu tersedia tanpa melihat musim (musim penghujan). 


\section{Motivasi Petani Mempertahankan Bibit Lokal}

Berdasarkan hasil penelitian tingkat motivasi petani mempertahankan bibit lokal yang termasuk dalam kategori tinggi sebesar 39,5833 \%, kategori sedang sebesar 52,0833 \% dan kategori rendah sebesar 8,333\%. Dari wawancara yang dilakukan langsung kepada petani (M. Sianipar) sebagai informan "hami mamakke bibit lokal ala nungga sian najolo angka natua-tua mamakei las tahan leleng, musena bibit lokal on tahan tu hama dohot angka sahit-sahit ni suansuanan" (kami memakai bibit lokal karena sudah turun-temurun dan tahan lama, bibit lokal ini tahan terhadap hama dan penyakit).

Dari data di atas dapat dilihat bahwa tingkat motivasi petani mempertahankan bibit lokal termasuk dalam kategori sedang, hal ini disebabkan karena bibit lokal lebih tahan lama dan memiliki hasil panen yang lebih baik selain itu juga bibit tersebut sudah digunakan turun-temurun sehingga petani masih tetap mempertahankan bibit tersebut. Padi varietas lokal sudah adaptif dengan kondisi lingkungan setempat, maka dari itu tanaman varietas bibit lokal harus dibudidayakan dengan baik. Dalam hal ini pemerintah tidak perlu bersusah payah mengurusi pelepasan varietas, pemerintah hanya memfasilitasi dengan menyediakan sebanyak mungkin nutfah untuk dikembangkan swasta dan petani pemulia.

\section{Motivasi Petani Mempertahankan Penanaman Sekali dalam Setahun}

Berdasarkan hasil penelitian tingkat motivasi petani mempertahankan penanaman sekali dalam setahun yang termasuk dalam kategori tinggi sebesar $45,8333 \%$, kategori sedang sebesar $50 \%$ dan kategori rendah sebesar 4,1667\%. Dari wawancara yang dilakukan langsung kepada petani (Jannes Siagian) sebagai informan "hami tetap manuan eme sahali sataon mangihut tu tingki na pas curah ni udan, dang adong dope na barani mambaen dua hali manang tolu hali sataon mabiar hasil na dang sesuai jala molo holan piga-piga halak mambaen annon angka hama dohot penyakit ma na unggodang mangallang eme $i^{\prime \prime}$ ( petani tetap mempertahankan penanaman sekali dalam setahun mengikuti curah hujan yang pas, belum ada yang berani menanam dua atau tiga kali dalam setahun karena takut menerima resiko kegagalan sebab apabila hanya beberapa yang melakukannya maka hama dan penyakit padi yang akan rentan memakannya).

Dari data di atas dapat dilihat bahwa tingkat motivasi petani mempertahankan penanaman sekali dalam setahun termasuk dalam kategori sedang, hal ini disebabkan karena pada saat setelah panen petani lebih memilih melakukan usahatani lain atau mengganti fungsi sawah menjadi kolam ketimbang harus menanam padi kembali. Hal ini dikarenakan untuk menghindari hama dan kesuburan tanah akan lebih terjaga. Akan tetapi petani juga memiliki keinginan untuk mencoba penanaman dua kali setahun apabila sistem tersebut dilakukan oleh seluruh petani padi secara serentak, karena apabila hanya dilakukan oleh beberapa petani saja maka akan menyebabkan kerugian karena terserang hama. 


\section{Faktor-Faktor yang Berhubungan dengan Motivasi Petani Mempertahankan Sistem Tradisional}

Untuk melihat bentuk dan kekuatan hubungan antara variabel bebas (pendidikan formal, pendidikan non formal, persepsi petani terhadap sistem tradisional, pengalaman berusahatani, luas lahan garapan dan jumlah tanggungan keluarga) dengan variabel terikat (motivasi mempertahankan sistem tradisional) dapat menggunakan Uji Korelasi Rank Spearman dengan menggunakan faktor koreksi. Sedangkan pengujian hipotesa dilakukan dengan melihat hasil $t$-hitung yang kemudian dibandingkan dengan $t$ tabel dimana pengujian ini bertujuan untuk melihat apakah terdapat hubungan nyata atau tidak antara variabel bebas dengan variabel terikat.

Tabel 1. Hasil Perhitungan Uji Korelasi Rank Spearman dan Nilai $t_{\text {hitung antara }}$ Variabel Bebas dan Motivasi Mempertahankan Sistem Tradisional

\begin{tabular}{llcc}
\hline No. & \multicolumn{1}{c}{ Variabel Bebas } & Nilai & Korelasi t hitung(rs2) \\
\hline 1 & Pendidikan formal (X1) & 0,3657 & $2,6652^{*}$ \\
2 & Pendidikan non formal (X2) & 0,1905 & 1,3164 \\
3 & Persepsi terhadap sistem & $-0,0874$ & $-0,5954$ \\
& tradisional (X3) & & \\
4 & Pengalaman berusahatani (X4) & 0,3829 & $2,8114^{*}$ \\
5 & Luas lahan garapan (X5) & $-0,0967$ & $-0,6596$ \\
6 & Jumlah tanggungan keluarga (X6) & 0,0277 & 0,1884 \\
\hline
\end{tabular}

Ket *: berhubungan nyata pada tingkat kepercayaan $95 \%(\alpha / 2=0,025)$ dengan $t$ tabel 2,011

Tabel 1 di atas dapat dilihat bahwa faktor-faktor yang berhubungan nyata terhadap motivasi petani dalam mempertahankan sistem tadah hujan yaitu pendidikan formal (X1), Pengalaan berusahatani (X4).

\section{Pendidikan Formal}

Berdasarkan hasil perhitungan Rank Spearman (tabel 1) nilai koefisien korelasi variabel pendidikan formal sebesar 0,3657 hal ini berarti bahwa apabila pendidikan formal meningkat maka motivasi petani dalam mempertahankan sistem tradisional akan meningkat.

Hal ini disebabkan karena semakin berkembangnya pengetahuan petani dan teknologi sekarang ini sehingga petani ingin mengikuti perkembangan jaman ke arah yang lebih modern seperti mengharapkan adanya pengairan sawah yang lebih baik selain tadah hujan yaitu irigasi, pendidikan formal yang dimiliki petani dapat menjamin petani untuk tetap mempertahnkan bibit lokal dalam berbuat atau berusaha sesuai dengan tingkat pendidikan formal yang dimilikinya, sebab usahatani yang dilakukan juga dipengaruhi oleh kemampuan petani itu sendiri dan situasi serta kondisi masyarakat petani sekitarnya walaupun hanya melakukan penanaman sekali dalam setahun. 
Menurut Dewi (2005) tingkat pendidikan petani juga akan mempengaruhi pengambilan keputusan dalam kegiatan pengelolaan usahataninya. Petani yang berpendidikan rendah akan merasa kesulitan dalam mengambil keputusan terhadap alokasi sumberdaya yang dimilikinya. Maka secara tidak langsung berpengaruh terhadap motivasi petani dalam mempertahankan sistem tradisional pada usahataninya.

Hasil penelitian ini sejalan dengan hasil penelitian Susantyo (2001) menyebutkan bahwa pendidikan formal berhubungan nyata dengan motivasi petani berusahatani di dalam kawasan hutan, wilayah Bandung Selatan (kasus petani peserta program perhutanan sosial di wilayah kesatuan pemangku hutan Bandung Selatan).

Hasil penelitian ini sejalan dengan hasil penelitian (Agussabti, 1998 dan Yuhana, 1983) menyebutkan bahwa tingkat pendidikan merupakan salah satu faktor yang mempengaruhi motivasi petani.

Kemudian hasil uji $\mathrm{t}$ menunjukkan bahwa t-hitung 2,6652 lebih besar dari t-tabel 2,011 sehingga terima Ha yang berarti ada hubungan nyata pada taraf kepercayaan 95\%, diantara peningkatan pendidikan formal dengan meningkat motivasi petani dalam mempertahankan sistem tradisional padi sawah.

\section{Pendidikan Non Formal}

Berdasarkan hasil perhitungan menggunakan Rank Spearman (tabel 1) nilai koefisien korelasi variabel pendidikan non formal sebesar 0,1905 hal ini berarti bahwa apabila pendidikan non formal meningkat maka motivasi petani dalam mempertahankan sistem tadah hujan padi sawah akan meningkat.

Hal ini hanya sebagai penambah dari ilmu yang telah dimiliki petani dalam melakukan usahatani padi sistem tradisional, karena pelatihan dan penyuluhan yang diterima oleh petani merasa masih sangat sedikit intensitasnya sehingga ilmu yang diterima dari hasil penyuluhan atau pelatihan tersebut juga tidak terlalu besar manfaatnya dan petani juga beranggapan bahwa penyuluhan sering bersifat konseptual dan tidak praktis sehingga para petani tidak terlalu antusias apabila ada penyelenggaraan penyuluhan bibit lokal dan penanaman sekali dalam setahun ataupun dalam bentuk yang lainnya.

Hasil penelitian ini tidak sejalan dengan hasil penelitian Soekartawi (2004) menyebutkan bahwa melalui aktivitas dalam mengikuti penyuluhan, pelatihan atau kursus pertanian yang diikuti petani, dapat meningkatkan pengetahuan serta keterampilan petani, sehingga makin tinggi frekuensi mengikuti penyuluhan, pelatihan dan kursus pertanian maka makin cepat proses penerapan inovasi baru atau perubahan terbaru sehingga petani dapat menerima inovasi baru di bidang pertanian

Kemudian hasil uji t menunjukkan bahwa t-hitung 1,3164 lebih kecil dari ttabel 2,011 sehingga terima Ho yang berarti tidak ada hubungan nyata pada taraf kepercayaan 95\%, diantara peningkatan pendidikan non formal dengan peningkatan motivasi petani dalam mempertahankan sistem tadah hujan padi sawah. 


\section{Persepsi Petani Terhadap Sistem Tradisional}

Berdasarkan hasil perhitungan menggunakan Rank Spearman (tabel 1) nilai koefisien korelasi variabel persepsi petani terhadap sistem tradisional sebesar $-0,0874$ hal ini berarti bahwa apabila persepsi petani terhadap sistem tradisional meningkat maka motivasi petani dalam mempertahankan sistem tradisional akan menurun.

Hal ini disebabkan karena petani tidak memiliki pendapat dan respon yang baik terhadap sistem tadah hujan yang akan memberikan manfaat pada petani, misalnya penghematan biaya irigasi karena tidak menggunakan irigasi tetapi memanfaatkan sistem tadah hujan atau alam. Menggunakan bibit lokal maka hasil produksi tidak dapat memenuhi kebutuhan keluarga sampai musim tanam berikutnya selain itu petani masih memiliki pandangan bahwa menggunakan bibit lokal merupakan trasisi turun- temurun dan mengikuti pola musim hujan yang hanya setahun sekali.

Hasil penelitian ini tidak sejalan dengan hasil penelitian Nur (2005) menyebutkan bahwa persepsi berhubungan nyata dengan motivasi petani dalam pengelolaan kuhuma di areal hutan rakyat (Kasus: Kecamatan Sawerigadi Kabupaten Muna).

Kemudian hasil uji t menunjukkan bahwa t-hitung -0,5954 lebih besar dari t-tabel $-2,011$ sehingga terima Ha yang berarti ada hubungan tidak nyata pada taraf kepercayaan $95 \%$, diantara peningkatan persepsi petani terhadap sistem tradisional dengan peningkatan motivasi petani dalam mempertahankan sistem tradisional.

\section{Pengalaman Berusahatani Sistem Tradisional}

Berdasarkan hasil perhitungan menggunakan Rank Spearman (tabel 1) nilai koefisien korelasi variabel pengalaman berusahatani sistem tradisional sebesar 0,3829 hal ini berarti bahwa apabila pengalaman berusahatani sistem tradisional meningkat maka motivasi petani dalam mempertahankan sistem tradisional padi sawah akan meningkat.

Hal ini disebabkan karena pengalaman berusahatani sistem tradisional banyak berpengaruh terhadap kegiatan usahatani hal ini dikarenakan semangat atau minat para petani untuk melakukan usahatani padi, kerena baik petani yang baru memulai usahatani padi maupun yang sudah lama pada dasarnya memiliki tujuan dan harapan yang sama yaitu ingin memenuhi kebutuhan hidup dengan menggunakan bibit lokal yang disebabkan oleh kebiasaan dalam melakukan pekerjaannya dan petani juga memiliki rasa kebersamaan dalam penanaman sekali dalam setahun dan tanggung jawab terhadap pekerjaanya, rasa kebersamaan timbul karena mereka merasa senasib dan saling membutuhkan baik dalam kegiatan usahatani maupun dalam kehidupan seharihari.

Hasil penelitian ini tidak sejalan dengan hasil penelitian Beni (2005), yang menyatakan bahwa pengalaman kerja tidak berhubungan nyata dengan tingkat motivasi kerja karyawan PT. Askes Regional VI Jawa Tengah dan D.I.Y bagian Sumber Daya Manusia dan Umum Semarang. 
Hasil penelitian ini juga sejalan dengan hasil penelitian Susantyo (2001) menyebutkan bahwa pengalaman beusahatani berhubungan nyata dengan motivasi petani berusahatani di dalam kawasan hutan, wilayah Bandung Selatan (kasus petani peserta program perhutanan sosial di wilayah kesatuan pemangku hutan Bandung Selatan).

Hasil penelitian ini tidak sejalan dengan hasil penelitian Taufik (2002) menyebutkan bahwa pengalaman tidak berhubungan nyata dengan motivasi pengrajin dalam usaha meningkatkan pendapatan melalui industri kerajinan sepatu sandal (Kasus pengrajin sepatu sandal di kelurahan Cikaret, kota Bogor)

Kemudian hasil uji $\mathrm{t}$ menunjukkan bahwa t-hitung 2,8114 lebih besar dari t-tabel 2,011 sehingga terima Ho yang berarti ada hubungan nyata pada taraf kepercayaan 95\%, diantara peningkatan pengalaman berusahatani sistem tradisional dengan peningkatan motivasi petani dalam mempertahankan sistem tradisional padi sawah.

\section{Luas Lahan Garapan}

Berdasarkan hasil perhitungan menggunakan Rank Spearman (tabel 1) nilai koefisien korelasi variabel luas lahan garapan sebesar -0,0967 hal ini berarti bahwa apabila luas lahan garapan meningkat maka motivasi petani dalam mempertahankan sistem tradisional padi sawah akan menurun.

Hal ini disebabkan karena luas lahan garapan diharapkan berhubungan dengan tingkat motivasi petani padi, karena dengan luas lahan yang semakin luas maka memungkinkan jumlah produksi yang dihasilkan lebih banyak dari lahan sehingga petani tetap melakukan penanaman sekali, hanya mengandalkan sistem tadah hujan dan menggunakan bibit lokal karena petani masih ragu-ragu dalam menerapkan suatu perubahan kearah yang lebih modern karena mereka takut mengambil resiko.

Hasil penelitian ini sejalan dengan hasil penelitian Hendra (2005), menyatakan bahwa luas lahan tidak berhubungan dengan tingkat motivasi kerja peternak sapi dalam meningkatkan kesejahteraan keluarga di Desa Pagar Dewa Kecamatan Kota Manna Kabupaten Bengkulu Selatan.

Hasil penelitian ini tidak sejalan dengan hasil penelitian Randi (2006), menyatakan bahwa luas lahan berhubungan dengan motivasi kerja petani kopi di Kecamatan Mulak Ulu Kotamadya Pagar Alam Provinsi Sumatera Selatan.

Kemudian hasil uji t menunjukkan bahwa t-hitung -0,6596 lebih besar dari t-tabel -2,011 sehingga terima Ho yang berarti tidak ada hubungan nyata pada taraf kepercayaan 95\%, diantara luas lahan garapan dengan penurunan motivasi petani dalam mempertahankan sistem tradisional padi sawah.

\section{Jumlah Tanggungan Keluarga}

Berdasarkan hasil perhitungan menggunakan Rank Spearman (tabel 1) nilai koefisien korelasi variabel jumlah tanggungan keluarga sebesar 0,0277 hal ini berarti bahwa apabila jumlah tanggungan keluarga meningkat maka motivasi petani dalam mempertahankan sistem tadah hujan padi sawah akan meningkat. 
Hal ini disebabkan karena petani beranggapan dengan jumlah tanggungan yang banyak dapat membantu dalam berusahatani dan dengan semakin banyak jumlah tanggungan bisa berpartisipasi dalam melakukan mina padi (padi palawija) atau (padi - ikan) untuk memenuhi kebutuhan dengan sistem tadah hujan, bibit lokal akan terus terbudidaya dan penanaman yang dilakukan sekali dalam setahun mengikuti musim penghujan.

Hasil penelitian ini sejalan dengan hasil penelitian Nur (2005) menyebutkan bahwa jumlah tanggungan keluarga tidak berhubungan nyata dengan motivasi ekologi petani dalam pengelolaan kahuma di areal hutan rakyat (Kasus: kecamatan Sawerigadi kabupaten Muna).

Hasil penelitian ini tidak sejalan dengan penelitian Mayangsari (2003) yaitu dengan bertambahnya jumlah anggota keluarga berarti akan memperbesar pengeluaran konsumsi rumah tangganya sehingga ibu rumah tangga akan lebih giat dalam berusaha.

Kemudian hasil uji t menunjukkan bahwa t-hitung 0,1884 lebih kecil dari ttabel 2,011 sehingga terima Ho yang berarti tidak ada hubungan nyata pada taraf kepercayaan 95\%, diantara jumlah tanggungan keluarga dengan peningkatan motivasi petani dalam mempertahankan sistem tradisional padi sawah.

\section{SIMPULAN DAN SARAN}

Tingkat motivasi petani mempertahankan sistem tradisional termasuk dalam kategori tinggi sebesar $50 \%$. Hal ini disebabkan karena tidak teraturnya keadaan iklim pada sekarang ini masyarakat cenderung ingin mempertahankan sistem tadah hujan dan mengusulkan kepada pemerintah agar memberi sarana irigasi kepada masyarakat sehingga manfaat dan keuntungan yang mereka dapatkan optimal, bibit lokal lebih tahan lama dan memiliki hasil panen yang lebih baik selain itu juga bibit tersebut sudah digunakan turun-temurun sehingga petani masih tetap mempertahankan bibit tersebut. Akan tetapi petani memiliki keinginan untuk mencoba bibit unggul untuk mengetahui apakah hasilnya lebih baik dari bibit lokal, pada saat setelah panen petani lebih memilih melakukan usahatani lain atau mengganti fungsi sawah menjadi kolam ketimbang harus menanam padi kembali. Hal ini dikarenakan untuk menghindari hama dan kesuburan tanah akan lebih terjaga. Akan tetapi petani juga memiliki keinginan untuk mencoba penanaman dua kali setahun apabila sistem tersebut dilakukan oleh seluruh petani padi secara serentak, karena apabila hanya dilakukan oleh beberapa petani saja maka akan menyebabkan kerugian karena terserang hama.

Faktor-faktor yang berhubungan nyata dengan motivasi petani mempertahankan sistem tradisional adalah pendidikan formal dan pengalaman berusahatani sistem tradisional sedangkan pendidikan non formal, persepsi petani terhadap sistem tradisional usahatani padi, luas lahan garapan, jumlah 
tanggungan keluarga, tidak berhubungan nyata dengan motivasi petani mempertahankan sistem tradisional. Faktor yang berhubungan nyata dengan motivasi petani mempertahankan sistem tradisional (sistem tadah hujan, bibit lokal dan penanaman setahun sekali) sebaiknya dijadikan bahan pertimbangan bagi petani dalam mempertahankan sistem tradisional padi sawah sehingga petani dapat mengambil sikap yang bijak.

Perlu kajian yang mendalam mengenai sistem tradisional dimasa yang akan datang, sehingga akan menyadarkan berbagai kalangan khususnya pemerintah setempat mengenai kesejahtera yang akan diterima oleh petani dalam panjang dari berbagai aspek.

\section{DAFTAR PUSTAKA}

Beni, H. 2005. Faktor-Faktor yang Mempengaruhi Motivasi Kerja Karyawan Di PT. Askes Regional VI Jawa Tengah dan DIY Bagian Dari Sumberdaya Manusia dan Umum Semarang. Tugas Akhir Jurusan Ekonomi Program Studi Manajemen Perkantoran DIII Fakultas Ilmu sosial Universitas Negeri Semarang. Semarang.

Dewi, K.R. Dan Sudiarti. 2005. Faktor Sosial Ekonomi yang Mempengaruhi Pengambilan Keputusan Petani dalam Sistem Penjualan Sayuran. Jurusan Sosial Ekonomi Pertanian Fakultas Pertanian Universitas Udayana (Tidak Dipublikasikan). Denpasar

Hendra. 2005. Faktor-Faktor yang Berhubungan Dengan Tingkat Motivasi Kerja Peternak Sapi dalam Menigkatkan Kesejahteraan Keluarga di Desa Pagar Dewa Kecamatan Manna Kabupaten Bengkulu Selatan . Skripsi Fakultas Ilmu Sosial dan Ilmu Politik Ekonomi Pertanian, Universitas Bengkulu. Bengkulu Tidak Dipublikasikan

Nazir. M. 1988. Metode Penelitian. Gramedia. Jakarta.

Nur,H. 2005. Motivasi Petani di dalam Pengelolaan Kahuma Di Areal Hutan Rakyat. Sekolah Pascasarjana. Institut Pertanian Bogor. Bogor

Randi, N. 2006. Analisa Faktor-Faktor Yang Berhubungan Dengan Tingkat Motivasi Kerja Petani Kopi di Kecamatan Mulak Ulu Kota Pagar Alam Propinsi Sumtera Selatan. Skripsi Jurusan Sosial Ekonomi Pertanian, Fakultas Pertanian, Universitas Sriwijaya. Palembang. Tidak Dipublikasikan

Soekartawi, 2004. Prinsip Dasar Ekonomi Pertanian Teori Dan Aplikasinya. PT. Rajawali Perss. Jakarta

Susantyo, B. 2001. Motivasi Petani Berusahatani Di Dalam Kawasan Hutan Wilayah Bandung Selatan. Tesis Pascasarjana. Institut Pertanian Bogor. Bogor 
ISSN: 1412-8837

\section{LAMPIRAN}

\section{DAFTAR ISTILAH}

$\begin{array}{ll}\text { Adong } & \text { : ada } \\ \text { Aek } & \text { : air } \\ \text { Dang } & \text { : tidak } \\ \text { Dohot } & \text { : ikut } \\ \text { Eme } & \text { : padi } \\ \text { Hali } & \text { : kali } \\ \text { Hami } & \text { : kami } \\ \text { Leleng } & \text { : lama } \\ \text { Mabiar } & \text { : takut } \\ \text { Mabiar } & \text { : takut } \\ \text { Mamakke } & \text { : memakai } \\ \text { Mambaen } & \text { : membuat } \\ \text { Manang } & \text { : atau }\end{array}$

$\begin{array}{ll}\text { Mananom } & \text { : menanam } \\ \text { Mangallang } & \text { : memakan } \\ \text { Mangihut } & \text { : mengikuti } \\ \text { Martani } & \text { : bertani } \\ \text { Natua-tua } & \text { : orang tua } \\ \text { Nungga } & \text { : sudah } \\ \text { Sahali } & \text { : sekali } \\ \text { Sahit } & \text { : penyakit } \\ \text { Sataon } & \text { : setahun } \\ \text { Suan-suanan } & \text { : tanaman } \\ \text { Udan } & \text { : hujan } \\ \text { Unggodang } & \text { : lebih banyak }\end{array}$

